\title{
PSA Level Less than or Equal to Thirty
}

National Cancer Institute

\section{Source}

National Cancer Institute. PSA Level Less than or Equal to Thirty. NCI Thesaurus. Code C142129.

A blood concentration of prostate specific antigen less than or equal to $30 \mathrm{ng} / \mathrm{mL}$. 